\title{
In vitro antigenotoxic activities of lichens Cetraria islandica and Lasallia pustulata
}

\author{
OLIVERA MILOŠEVIĆ-DJORDJEVIĆ ${ }^{1,2 *}$, DARKO GRUJIČIĆ1 ${ }^{2}$ BRANISLAV \\ RANKOVIĆ ${ }^{1}$, MARIJANA KOSANIĆ ${ }^{1}$
}

${ }^{1}$ University of Kragujevac, Faculty of Science, Department of Biology and Ecology, 34000, Kragujevac, Serbia ${ }^{2}$ University of Kragujevac, Faculty of Medical Sciences, Department of Genetics, 34000, Kragujevac, Serbia

\begin{abstract}
It has long been known that lichens are popular in folk medicine due to biological activities such as antitumor, antimicrobial and antioxidant. Thus, in this study we aimed to investigate antigenotoxic effects of $C$. islandica and $L$. pustulata methanol extracts on cultured human peripheral blood lymphocytes (PBLs). Genome damage was determined using cytokinesis-block micronucleus (MN) assay. Peripheral blood was collected by venipuncture from healthy donors and the known mutagen mitomycin C (MMC) was used to determine antigenotoxic properties of the tested concentrations of methanol extracts from the lichens $(12.5,25,50,100$ and $200 \mu \mathrm{g} / \mathrm{ml})$. The tested extracts dose dependently decreased MMC-induced MN frequencies, but significantly only in the highest concentrations (100 and $200 \mu \mathrm{g} / \mathrm{ml}$ ). Both extracts dose dependently decreased nuclear division index (NDI) in MMC-treated PBLs. There were significantly lower NDI values in the treatments with all tested concentrations of both extracts, except two lowest of $L$. pustulata extract, in comparison to the untreated cells $(\mathrm{P}<0.05)$. Our results suggest that $\mathrm{C}$. islandica and L. pustulata lichen extracts should be recommended for use in the protection against anticancer drugs and safely in higher concentrations because they are more effective than.
\end{abstract}

Keywords Cetraria islandica, Lasallia pustulata, lichens, antigenotoxic activity, human peripheral blood lymphocytes.

To cite this article: MILOŠEVIĆ-DJORDJEVIĆ O, GRUJIČIĆ D, RANKOVIĆ B, KOSANIĆ M. In vitro antigenotoxic activities of lichens Cetraria islandica and Lasallia pustulata. Rom Biotechnol Lett. 2020; 25(5): 1915-1921. DOI: 10.25083/rb1/25.5/1915.1921

$\square$ *Corresponding author: OLIVERA MILOŠEVIĆ-DJORDJEVIĆ, Faculty of Science, University of Kragujevac, Radoja Domanovića 12, 34 000, Kragujevac, Serbia

E-mail: olivera.djordjevic@pmf.kg.ac.rs $\quad$ Tel +38134335-039 $\quad$ Fax +38134335040 


\section{Introduction}

Lichens are complex organisms consisting of a symbiotic association of a fungal and an algal partner [1]. More than 20,000 known species of lichens have been identified to inhabit diverse ecosystems ranging from arctic tundra to desert climates [2]. They are ubiquitous on barks, stems, leaves and in soil, but often grow in habitats less favorable for higher plants [3]. Some lichen species have historically been used as food dyes, in the production of alcohol and perfume industry [4]. Moreover, for a long time, these organisms have been used in traditional medicine in the treatments of numerous infectious diseases, such as stomach diseases, diabetes, coughs, pulmonary tuberculosis, wound curing, and dermatological diseases $[5,6]$. The use of lichens in medicine is based on the fact that they contain unique and varied biologically active secondary metabolites that may be pharmacologically potent [7].

Lichen's secondary metabolites, called lichen acid, are synthetized mostly by the fungal partner. Although produced within the hyphae, they are deposited as crystals on the surface. Previous studies show that they have very different biological activities such as antibacterial, antiviral, antioxidant, anti-proliferative, cytotoxic, antiinflammatory and antipyretic activities [8, 9]. The secondary metabolites are soluble in water and can usually be isolated from the lichen crystals using organic solvents [10]. More than 1000 such secondary metabolites have been detected and isolated [11]. Numerous researches determined different activities for lichens, for different extraction solvents used, but many times is found that the methanol extract showed the strongest activity because in methanol dissolves the largest number of lichen secondary metabolites which are responsible for the activity of the lichen [12, 13].

Cetraria islandica (L.) commonly known as Iceland moss is the most commonly utilized lichen and has been included among the drugs listed in 50 pharmacopoeias or dispensatories of the period 1840s in Europe [14], also been screened for various biological activity. In traditional medicine $C$. islandica was used to treat mild inflammation of the oral and pharyngeal mucosa, dyspepsia and loss of appetite and in European folk medicine in cancer treatment [15]. Also, some earlier studies have shown that methanol extract of $C$. islandica collected from Iceland exhibited cancer chemopreventive and cytotoxic activity [16], as well in cultured tissue exhibited activity towards tyrosine inhibition and gram +ve bacteria such as Bacillus subtilis, Propionibacterium acnes and Staphylococcus aureus [17]. In our previous study we showed that only higher tested concentrations of methanol extract obtained from Cetraria islandica $(50,100$ and $200 \mu \mathrm{g} / \mathrm{ml})$ induced genotoxic effects in human PBLs of healthy donors, using micronucleus test [18].

Lasallia pustulata is a large, foliose species, which contains the lichen substances gyrophoric acid, arabitol, mannitol and umbilicarin [19]. There is very little literature data on the biological activity of L. pustulata, but there is mostly data on its taxonomy. Our previous published results showed that methanol extract of L. pustulata exhibits an antioxidant, antimicrobial and anticancer activities in vitro [20].

In determining genotoxic effects of physical, chemical and biological agents, the micronucleus test in human peripheral blood lymphocytes (PBLs) is an attractive cytogenetic end point for assessing in vitro [21, 22] and in vivo exposure [23, 24]. Micronuclei indirectly reflect chromosome damage because they are formed of chromosome/chromatid fragments or whole chromosomes, which are lost during cell division.

The objective of the present study was to investigate the antigenotoxic activities of methanol extracts obtained from lichens Cetraria islandica and Lasallia pustulata against the mitomycin $\mathrm{C}$-induced genotoxicity in human peripheral blood lymphocytes (PBLs) in vitro, using cytokinesis-block micronucleus (MN) assay.

\section{Material and Methods}

\section{Collection and identification of lichen samples}

Lichen samples of Cetraria islandica (L.) Ach., and Lasallia pustulata (L.) Merat, were collected from Kopaonik, Serbia, in September of 2011, and authenticated by Dr B. Ranković and Dr M. Kosanić at the Faculty of Science, University of Kragujevac. Determination of the investigated lichens was accomplished using standard keys $[25,26]$. The voucher specimen of the lichen (Voucher no. 148 and 153) was deposited at the Mycological Laboratory within the Department of Biology and Ecology at the Faculty of Science, University of Kragujevac, Serbia.

\section{Preparation of lichen extracts}

Finely dry ground thalli of the examined lichen (100 g) were extracted using methanol in a Soxhlet extractor. The extract was filtered and then concentrated under the reduced pressure in a rotary evaporator. The dry extract was stored at $-18^{\circ} \mathrm{C}$ until it was used in the tests. The extract was dissolved in 5\% dimethyl sulphoxide (DMSO) for the experiments. DMSO was dissolved in sterile distilled water to the desired concentration.

\section{Blood samples}

Peripheral blood was collected by venipuncture from three healthy donors aged 30-34 years, nonsmokers, who had not been exposed to known mutagens. Blood was kept at room temperature for the shortest time, within 2 hours. The experiments were conformed to the guidelines of the World Medical Assembly (Declaration of Helsinki).

\section{Cytokinesis-block micronucleus (MN) assay}

Cytokinesis-block MN assay was performed as described by FENECH [27]. Whole heparinised blood $(0.5 \mathrm{ml})$ was added to $5 \mathrm{ml}$ of peripheral blood karyotyping medium with phytohemagglutinin $\left(\mathrm{GIBCO}^{\mathrm{TM}} \mathrm{PB}-\mathrm{Max}^{\mathrm{TM}}\right.$, Invitrogen, California, USA). Cultures were incubated for 72 hours at $37^{\circ} \mathrm{C}$. Cytochalasin-B (Sigma, St. Louis, MO, USA) dissolved in DMSO was added to cultures 44 hours after the beginning of incubation, in a concentration of $4.0 \mu \mathrm{g} / \mathrm{ml}$. The cultures were re-incubated and harvested 28 hours later. First, the cells were collected by 
centrifugation and then treated with cold $\left(4^{\circ} \mathrm{C}\right)$ hypotonic solution $(0.56 \% \mathrm{KCl})$. Then, the cells were fixed three times with methanol and glacial acetic acid at a 3:1 ratio. The cells suspensions were dropped onto slides and stained with $2 \%$ Giemsa.

The analysis of MN was performed using a light microscope (Nikon E50i) at $400 \mathrm{x}$ magnification following the criteria for $\mathrm{MN}$ scoring in binucleated (BN) cells only, described by FENECH [27]. Each slide was scored for the number of $\mathrm{MN}$ and the distribution of binucleate $(\mathrm{BN})$ cells with 1 or more MN. The frequency of micronucleated $\mathrm{BN}$ cells found in $3000 \mathrm{BN}$ cells per tested concentration of extracts (1000 per donor) was scored as well as the proportion of mononucleated, binucleated, trinucleated and tetranucleated cells per 500 cells. Nuclear division index (NDI) was calculated using the formula NDI $=((1 \times \mathrm{x} 1+$ $(2 \times \mathrm{M} 2)+(3 \times \mathrm{M} 3)+(4 \times \mathrm{M} 4)) / \mathrm{N}$, where M1 - M4 are the number of cells with 1 to 4 nuclei, and $\mathrm{N}$ is the number of the scored cells FENECH [27].

2.4.1. In vitro antigenotoxicity assessment

Methanol C. islandica and L. pustulata extracts in the same five concentrations $(12.5,25,50,100$ and $200 \mu \mathrm{g} / \mathrm{ml})$ were added separately to lymphocyte cultures 24 hours after the beginning of incubation. Mitomycin C (MMC, Sigma, St. Louis, MO, USA) was added to cell cultures in the concentration of $0.5 \mu \mathrm{g} / \mathrm{ml}$ concomitantly with lichen extract and alone (positive control).

\section{Statistical analysis}

SPSS Statistics 20 package was used for statistical analysis, applying the paired $t$-test for comparison mean MN frequencies and NDI values between different treatments. A $P$ value of less than 0.05 was considered statistically significant. All data are expressed as mean \pm standard deviation (S.D.). The relationship between the tested concentrations of extracts and MN and NDI was determined by Pearson correlation coefficients.

\section{Results and Discussion}

The results of in vitro combined activities of methanol extracts obtained from C. islandica and L. pustulata and MMC in cultured human PBLs are shown in Tables 1 and 2, and Figures 1-4.

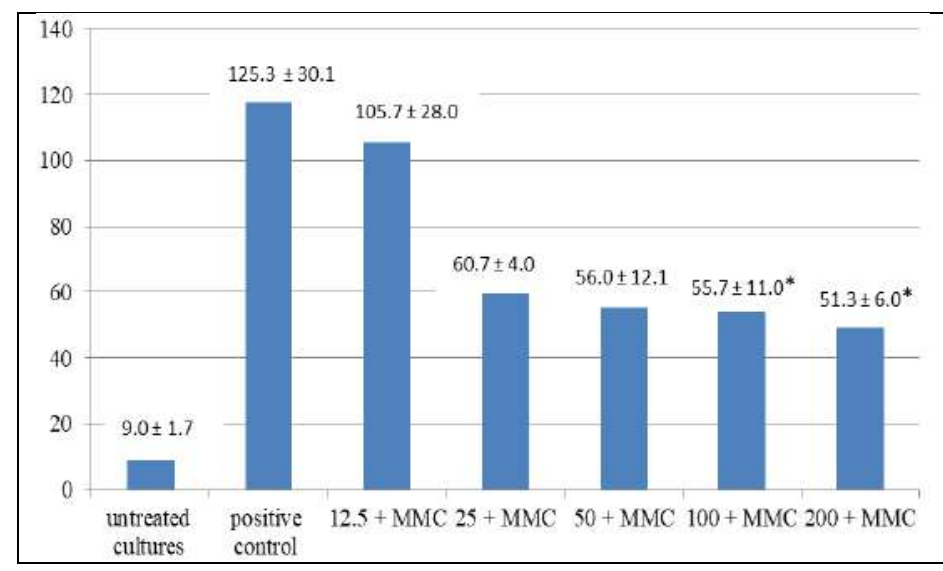

Figure 1. The micronuclei frequencies in cultured peripheral blood lymphocytes after the combined treatments with different concentrations of Cetraria islandica extract and mitomycin $\mathrm{C}$ $(0.5 \mu \mathrm{g} / \mathrm{ml})$ (*statistical significance).

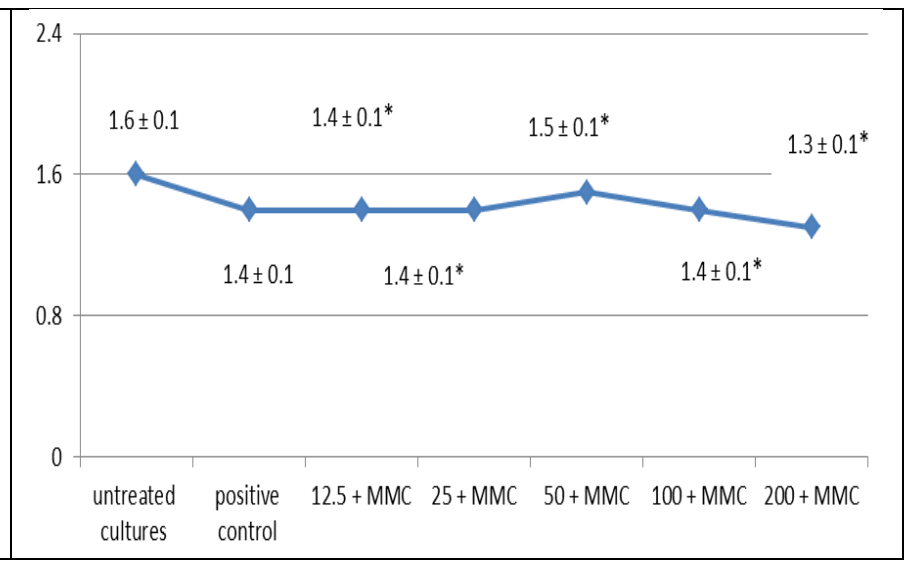

Figure 2. The nuclear division index (NDI) of cultured peripheral blood lymphocytes after the treatments with different concentrations of Cetraria islandica extract and mitomycin C $(0.5 \mu \mathrm{g} / \mathrm{ml})$ (*statistical significance).

Table 1. The distribution of micronuclei in cultured peripheral blood lymphocytes (PBLs) of healthy donors after the combined treatments with methanol Cetraria islandica extract and mitomycin $\mathrm{C}(0.5 \mu \mathrm{g} / \mathrm{ml})$

\begin{tabular}{|c|c|c|c|c|c|c|c|}
\hline \multirow{2}{*}{ Treatments } & \multirow{2}{*}{$\begin{array}{c}\text { Extract } \mu \mathrm{g} / \mathrm{ml}+ \\
\text { MMC }\end{array}$} & \multirow{2}{*}{$\begin{array}{c}\text { No of } \\
\text { analyzed } \\
\text { BN cells }\end{array}$} & \multirow{2}{*}{$\begin{array}{c}\text { BN with MN } \\
(\%)\end{array}$} & \multicolumn{4}{|c|}{ Distribution of MN } \\
\hline & & & & $1 \mathrm{MN}(\%)$ & $2 \mathrm{MN}(\%)$ & $3 \mathrm{MN}(\%)$ & $4 \mathrm{MN}(\%)$ \\
\hline Untreated cells & 0 & 3000 & $26(0.9)$ & $25(0.8)$ & $1(0.0)$ & I & I \\
\hline \multirow[t]{3}{*}{ Positive control } & MMC & 3000 & $315(10.5)$ & $266(8.9)$ & $37(1.2)$ & $12(0.4)$ & I \\
\hline & $12.5+\mathrm{MMC}$ & 3000 & $278(9.3)$ & $244(8.1)$ & $30(1.0)$ & $3(0.1)$ & $1(0.0)$ \\
\hline & $25+\mathrm{MMC}$ & 3000 & $172(5.7)$ & $162(5.4)$ & $10(0.3)$ & I & I \\
\hline \multirow[t]{3}{*}{ C. islandica } & $50+\mathrm{MMC}$ & 3000 & $156(5.2)$ & $144(4.8)$ & $12(0.4)$ & l & l \\
\hline & 100+MMC & 3000 & $156(5.2)$ & $145(4.8)$ & $11(0.4)$ & l & l \\
\hline & 200+MMC & 3000 & $145(4.8)$ & $136(4.5)$ & $9(0.3)$ & l & l \\
\hline
\end{tabular}


Figures 1 and 2 show the effects of concomitant treatments with five concentrations of $C$. islandica extract and MMC on MN frequency and NDI. MMC alone significantly increased the $\mathrm{MN}$ frequency in PBLs in comparison to untreated PBLs $(P<0.05)$. All tested concentrations of this extract decreased the MMC-induced $\mathrm{MN}$ frequencies dose dependently $(\mathrm{r}=-0.591, P<0.05)$ but significantly only at the highest tested concentrations (100 and $200 \mu \mathrm{g} / \mathrm{ml}$ ) compared to positive control cells, with probability $P<0.05$ (Figure 1 ). There was significant dose dependent decrease of NDI $(r=-0.525, P<0.05)$ in MMC-induced PBLs at all tested extract concentrations in comparison to the untreated PBLs (Figure 2). The difference in the NDI was observed between the untreated and positive control PBLs (MMC alone), too.
The analysis of $\mathrm{MN}$ distribution revealed that all tested concentrations of the extract decreased both the number of $\mathrm{MMC}$-induced $\mathrm{BN}$ cells with $\mathrm{MN}$ and the number of MMC- induced MN in BN cells, but significantly only in the treatments with 100 and $200 \mu \mathrm{g} / \mathrm{ml}$ concentrations of extract. The greatest number of micronucleated $\mathrm{BN}$ cells had $1 \mathrm{MN}$ in both MMC alone (positive control) and in combined treatments with MMC and different concentrations of the extract. The BN cells with 2 $\mathrm{MN}$ were less present in all treatments. Cells with 3 and 4 MN were present only in two treatments of PBLs: MMC alone and in combination with the lowest tested concentration of the extract $(12.5 \mu \mathrm{g} / \mathrm{ml})$.

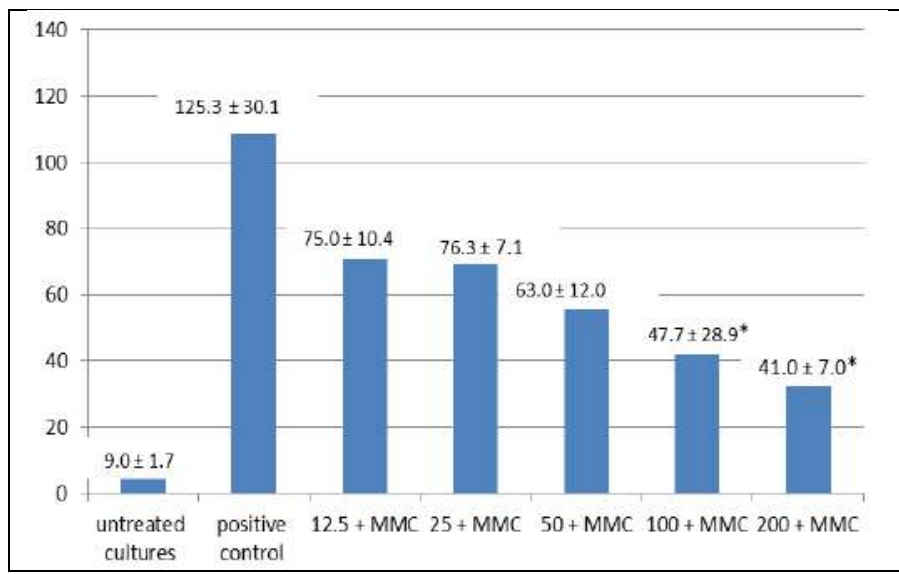

Figure 3. The micronuclei frequencies in peripheral blood lymphocytes after the combined treatments with different concentrations of extract from Lasallia pustulata and mitomycin $\mathrm{C}(0.5 \mu \mathrm{g} / \mathrm{ml})$ in vitro (*statistical significance).

Figures 3 and 4 represent the results of combined effects of five tested concentrations L. pustulata extract and MMC on MN frequency and NDI. It was observed that the extract reduced the MMC-increased MN frequency in PBLs in a dose dependent manner $(\mathrm{r}=-0,805, P<0.001)$, but a statistically significant decrease was found only at 100 and

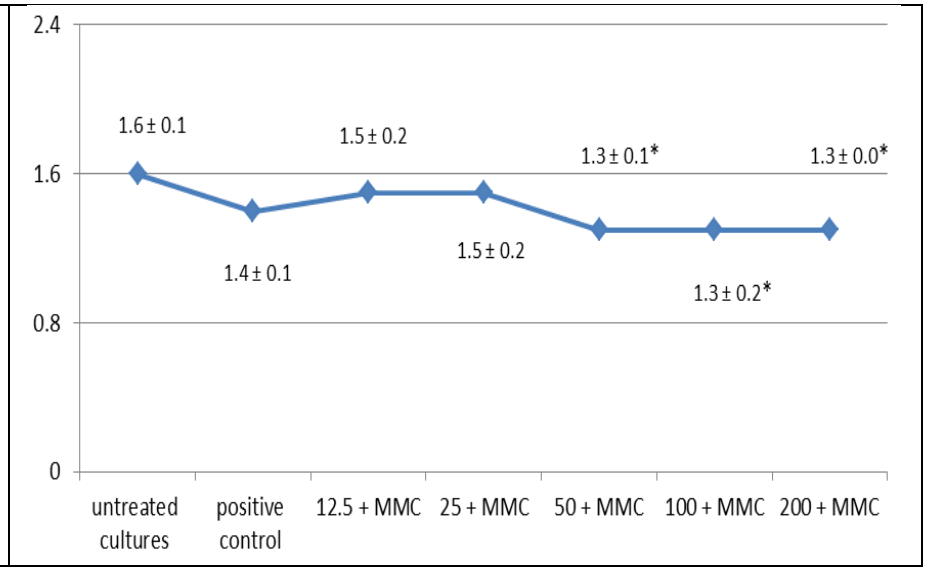

Figure 4. The nuclear division index (NDI) of peripheral blood lymphocytes after combined treatments with different concentrations of extract from Lasallia pustulata and mitomycin $\mathrm{C}$ $(0.5 \mu \mathrm{g} / \mathrm{ml})$ in vitro (*statistical significance).

$200 \mu \mathrm{g} / \mathrm{ml}$ concentrations, with probability $P<0.001$ (Figure 3). A significant dose dependent decrease of NDI values in MMC-treated PBLs $(\mathrm{r}=-0,659, \mathrm{P}<0.01)$ was obtained. Concentrations 50 to $200 \mu \mathrm{g} / \mathrm{ml}$ of the extract significantly lowered NDI in comparison to the untreated cells $(\mathrm{P}<0.05)$ (Figure 4).

Table 2. The distribution of micronuclei in peripheral blood lymphocytes (PBLs) of healthy donors after in vitro combined treatments with different concentrations of Lasallia pustulata extract and mitomycin C $(0.5 \mu \mathrm{g} / \mathrm{ml})$

\begin{tabular}{|c|c|c|c|c|c|c|c|}
\hline \multirow{2}{*}{ Treatments } & \multirow{2}{*}{$\begin{array}{c}\text { Extract } \mu \mathrm{g} / \mathrm{ml}+ \\
\mathrm{MMC}\end{array}$} & \multirow{2}{*}{$\begin{array}{c}\text { No of } \\
\text { analyzed } \\
\text { BN cells }\end{array}$} & \multirow{2}{*}{$\begin{array}{c}\text { BN with MN } \\
(\%)\end{array}$} & \multicolumn{4}{|c|}{ Distribution of $\mathrm{MN}$} \\
\hline & & & & $1 \mathrm{MN}(\%)$ & $2 \mathrm{MN}(\%)$ & $3 \mathrm{MN}(\%)$ & $4 \mathrm{MN}(\%)$ \\
\hline Untreated cells & 0 & 3000 & $26(0.9)$ & $25(0.8)$ & $1(0.0)$ & I & I \\
\hline \multirow[t]{3}{*}{ Positive control } & MMC & 3000 & $315(10.5)$ & $266(8.9)$ & $37(1.2)$ & $12(0.4)$ & I \\
\hline & 12.5+MMC & 3000 & 197 (6.6) & $169(5.6)$ & $28(0.9)$ & I & I \\
\hline & 25+MMC & 3000 & $208(6.9)$ & $188(6.3)$ & $19(0.6)$ & $1(0.0)$ & I \\
\hline \multirow[t]{3}{*}{ L. pustulata } & $50+\mathrm{MMC}$ & 3000 & $150(5.0)$ & $118(3.9)$ & $25(0.8)$ & $7(0.2)$ & I \\
\hline & 100+MMC & 3000 & $128(4.3)$ & $115(3.8)$ & $11(0.4)$ & $2(0.1)$ & I \\
\hline & 200+MMC & 3000 & $113(3.8)$ & $105(3.5)$ & $6(0.2)$ & $2(0.1)$ & I \\
\hline
\end{tabular}


The analysis of MN distribution (Table 2) revelead that micronucleated $\mathrm{BN}$ cells with $1 \mathrm{MN}$ were predominant, followed by significantly fewer cells with $2 \mathrm{MN}$, while the cells with $3 \mathrm{MN}$ were found in the cultures treated with 25-200 $\mu \mathrm{g} / \mathrm{ml}$ lichen extract and MMC and in positive control (MMC).

The results of the present study clearly showed that all tested concentrations of both $C$. islandica and L. pustulata extracts lowered the MMC-increased MN frequency in a dose dependent manner as well that the highest tested concentrations of both lichens (100 and $200 \mu \mathrm{g} / \mathrm{ml})$ were the most effective. The obtained results showed that both lichens extracts had protective effect in cultured human PBLs.

In accordance with our findings, recent studies have revealed a protective role of different lichen extracts. Until now, E.KOTAN \& al [33] studied anti-mutagenic activity of Cetraria islandica lichen and they reported that methanol extract of this species suppressed the mutagenic effects of aflatoxin B1. To our knowledge, no report is available on the anti-mutagenic effect of Lasallia pustulata, but our cytogenetic findings are in agreement with the results reported by the authors who studied in vitro effects of taxonomically similar lichens on human PBLs. H. TÜRKEZ \& al [21] found the anti-mutagenic effect of aqueous Peltigera rufescens extract against the mutagenic damage induced by imazalil. In addition, H. TÜRKEZ \& al [31] reported that Xanthoria elegans is a potential antigenotoxicant. Very recently S. CEKER \& al [34] reported that Usnea articulata and Usnea filipendula have strong antigenotoxic effect against aflatoxin B1-induced genotoxic damage and that its effect associated with lichen antioxidant nature.

MMC is a natural antitumor, antibiotic and cytotoxic agent, used against different tumors (gastric and esophageal carcinomas, bladder cancer), but in addition to cancer cells it causes high toxicity in the normal tissues during the therapy. It is known that MMC induces chromosomal aberrations during $\mathrm{S}$ phase and several mechanisms of its mutagenic and clastogenic effects are explained by its alkylating activity [29]. On the other hand, MMC produces covalent cross-linkages between opposite DNA strands [30] and it was found to have led to the development of oxidative stress [31] and the production of free radicals when metabolized [32].

The present study of treatment by the lichens extracts and MMC concomitantly, revealed a protective effect of the lichens extracts against chromosome damage induced by MMC.

The exact mechanism by which the lichens extract reduced genotoxic effect against MMC was not clear. There are two possible explanations of the obtained results: 1) increase in DNA repair and 2) induction of apoptotic cell death mechanisms in the cells which collect a large quantity of genetic damage.

In order to get the correct answer we investigated the NDI values. Our results indicated dose dependent decrease of NDI values in the PBLs concomitantly treated with MMC and lichen extract, when compared to the untreated
PBLs. Our results showed a decrease in MN frequencies, number of MNs per BN cell and number of micronucleated BN cells, too. This may lead to a conclusion that the tested extracts in the cells which collected a large quantity of MMC-increased genetic damage induced the apoptotic mechanisms of cell death. It can be a general mechanism of protective effect for the both extracts obtained from C. islandica and L. pustulata lichens.

Some authors showed that significant decrease of NDI in cultures of peripheral blood lymphocytes may be due to the fact that cells with greater chromosomal damage die before cell division [35]. C.J. NATH \& T. ONG [36] observed that $\mathrm{BN}$ cells with greater number of $\mathrm{MN}$ could be the result of the loss of major part of genome, which was enough to stop further division of these cells. Such cells are eliminated by apoptosis, which contributes to understanding the decrease of MN frequency [37]. S. PETROVIĆ $\&$ al [38] showed inverse relationship between $\mathrm{MN}$ and apoptosis, and concluded that damaged cells incapable to undergo apoptosis are mostly visible as binucleated cells carrying MN.

Induction of apoptosis is an important mechanism of chemoprevention and different studies suggest that polyphenols which are present in the lichens extracts have the primary role in the induction of apoptosis [39]. In this respect, polyphenols act as protection against genome instability [40].

\section{Conclusion}

The results of this study showed that methanol extracts obtained from $C$. islandica and L. pustulata lichens had highly protective effect, which we detected as a reduction in genome damage caused by a known mutagen. Our general conclusion is that methanol $C$. islandica and L. pustulata extracts should be recommended for use in the protection against anticancer drugs and safely in higher concentrations because they are more effective than.

\section{Acknowledgements}

The study was supported by grants from the Ministry of Education and Science of Republic of Serbia (Grant No III41010, 173032, 175103). The authors are grateful to all volunteers for the blood samples.

\section{Conflict of interest}

The authors declare that there is no conflict of interest associated with this work.

\section{References}

1. S.T. BATES, G.W. CROPSEY, J.G. CAPORASO, R. KNIGHT, N. FIERER. Bacterial communities associated with the lichen symbiosis. Appl. Environ. Microbiol. 77(4): 1309-1314 (2011).

2. G. OBOH, A.O. ADEMOSUN. Comparative studies on the ability of crude polyphenols from some nigerian citrus peels to prevent lipid peroxidation in vitro. Asian J. Biochem. 1(2): 169-177 (2006). 
3. H. VRABLIKOVA, M. MCEVOY, K.A. SOLHAUG, M. BARTAK, Y. GAUSLAA. Annual variation in photoacclimation and photoprotection of the photobiont in the foliose lichen Xanthoria parietina. J. Photochem. Photobiol B. 83(2): 151-162 (2006).

4. S. KIRMIZIGÜL, O. KOZ, H. ANI, S. ICLI. Isolation and structure elucidation of novel natural products from Turkish lichens. Turk. J. Chem. 27: 493-500 (200).

5. D. BOWN. Encyclopedia of herbs and their uses. Dorling Kindersley, London (1995).

6. S. DEVKOTA, R.P. CHAUDHARY, S. WERTH, C. SCHEIDEGGER. Indigenous knowledge and use of lichens by the lichenophilic communities of the Nepal Himalaya. J. Ethnobiol. Ethnomed. 13(1): 15. (2017).

7. M. BALASUBRAMANIAN, P. NIRMALA. Antimycobacterial activity of foliose lichens on plant and animal pathogens. IJPSR. 5(11): 4825-4831 (2014).

8. G. SHAWUTI, A. ABBAS. Research progress on biological activities of lichens secondary metabolites. Food Sci. J. 28(10): 624-627 (2007).

9. I. TAS, A.B. YILDIRIM, G.C. OZYIGITOGLU, M.Z. YAVUZ, A.U. TURKER. Determination of biological activities (antibacterial, antioxidant and antiproliferative) and metabolite analysis of some lichen species from Turkey. EJBPS. 4(04): 13-20 (2017).

10. S. OZTURK, S. GUVENC, N. ARIKAN, O. YILMAZ. Effect of usnic acid on mitotic index in root tips of Allium cepa L. Lagascalia. 21(1): 47-52 (1999).

11. K. MOLNAR, E. FARKA ̌́. Current results on biological activities of lichen secondary metabolites: a review. Z. Naturforsch. C. 65(3-4): 157-173 (2010).

12. E.M. IDAMOKORO, P. MASIKA, V. MUNCHENJE, E. GREEN. In-vitro antibacterial sensitivity of Usnea barbata lichen extracted with methanol and ethylacetate against selected Staphylococcus species from bovine milk. Mendelnet.; 203-206 (2013).

13. M.M. AL-DABBAS, Antioxidant activity of different extracts from the aerial part of Moringa peregrina (Forssk.) Fiori, from Jordan. Pak. J. Pharm. Sci. 30(6): 2151-2157 (2017).

14. K.O. VARITA. Lichen antibiotics. In The lichens, Ahmadjian V. \& Hale M.E. eds. Academic Press, New York, pp. 547-561 (1973).

15. A. CHEVALLIER. The encyclopedia of medicinal plants. Dorling Kindersley, London, (1996).

16. K. INGÓLFSDÓTTIR, S. KOOK LEE, K.P. BHAT, K. LEE, H.B. CHAI, H. KRISTINSSON, L.L. SONG, J. GILLS, J.T. GUDMUNDSDÓTTIR, E. MATAGREENWOOD, M.S. JANG, J.M. PEZZUTO. Evaluation of selected lichens from Iceland for cancer chemopreventive and cytotoxic activity. Pharm. Bio. 38(4): 313-317 (2000).

17. Y. YAMAMOTO, Y. KINOSHITA, H. MATSUBARA, K. KINOSHITA, K. KOYAMA, K. TAKAHASHI, T. KUROKAWA, I. YOSHIMURA. Screening of biological activities and isolation of biologicalactive compounds from lichens. Recent. Res. Devel. Phytochem. 2: 23-33 (1998).
18. D. GRUJIČIĆ, I STOŠIĆ, M KOSANIĆ, T. STANOJKOVIĆ, B. RANKOVIĆ, O. MILOŠEVIĆDJORDJEVIĆ. Evaluation of in vitro antioxidant, antimicrobial, genotoxic and anticancer activities of lichen Cetraria islandica. Cytotechnology. 66(5): 803813 (2014).

19. B. RANKOVIĆ, M. MIŠIĆ, S. SUKDOLAK. Evaluation of antimicrobial activity of the lichens Lasallia pustulata, Parmelia sulcata, Umbilicaria crustulosa and Umbilicaria cylindrical. Mikrobiol. 76(6): 817-821 (2007).

20. M. KOSANIĆ, B. RANKOVIĆ, T. STANOJKOVIĆ, I. STOŠIĆ, D. GRUJIČIĆ, O. MILOŠEVIĆDJORDJEVIĆ. Lasallia pustulata lichen as possible natural antigenotoxic, antioxidant, antimicrobial and anticancer agent. Cytotechnology. 68(4): 999-1008 (2016).

21. H. TÜRKEZ, E. AYDIN, T. SISSMAN, A. ASLAN. Role of Peltigera rufescens (Weis) Humb. (a lichen) on imazalil-induced genotoxicity: analysis of micronucleus and chromosome aberrations in vitro. Toxicol. Ind. Health. 28(6): 492-498 (2012).

22. O. MILOŠEVIĆ-DJORDJEVIĆ, I. STOŠIĆ, M. STANKOVIĆ, D. GRUJIČIĆ. Comparative study of genotoxicity and antimutagenicity of methanol extracts from Teucrium chamaedrys and Teucrium montanum in human lymphocytes using micronucleus assay. Cytotechnology. 65(5): 863-869 (2013).

23. C. ARISTEI, F. STRACCI, P. GUERRIERI, P. ANSELMO, R. ARMELLINI, A. RULLI, F. BARBERINI, P. LATINI, A.R. MENGHINI. Frequency of sister chromatid exchanges and micronuclei monitored over time in patients with early-stage breast cancer: results of an observational study. Cancer Genet. Cytogenet; 192(1): 24-29 (2009).

24. O. VRNDIĆ, O.MILOŠEVIĆ-DJORDJEVIĆ, LJ. MIJATOVIĆ-TEODOROVIĆ, M. JEREMIĆ, I. STOŠIĆ, D. GRUJIČIĆ, S. ŽIVANČEVIĆ-SIMONOVIĆ. Correlation between micronuclei frequency in peripheral blood lymphocytes and retention of 131-I in thyroid cancer patients. Tohoku J. Exp. Med. 229(2): 115-124 (2013).

25. O.W. PURVIS, B.J. COPPINS, D.L. HAWKSWORTH, P.W. JAMES, D.M. MOORE. The lichen flora of Great Britain and Ireland. Natural History Museum, Publications in association with the British Lichen Society, London (1992).

26. F. DOBSON. Lichens an illustrated guide. Richmond publishing Co London (2000).

27. M. FENECH. The in vitro micronucleus technique. Mutat. Res. 455(1-2): 81-95 (2000).

28. D.H.S. RICHARDSON. Medicinal and other economic aspects of lichens. In: Handbook of Lichenology ed. Galun M., Boca Raton, Florida, USA: CRC Press, p. 93-108. (1988).

29. I.D. ADLER. Aberration induction by mitomycin $\mathrm{C}$ in early primary spermatocytes of mice. Mutat. Res. 35(2): 247-256 (1976). 
30. P.H. LIAO, R.H. LIN, M.L. YANG, Y.C. LI, Y.H. KUAN. Evaluation of differential representative values between Chinese hamster cells and human lymphocytes in mitomycin-C induced cytogenetic assays and caspase-3 activity. Toxicol. Ind. Health. 28(2): 174-180 (2012).

31. H. TÜRKEZ, E. AYDIN, A. ASLAN. Xanthoria elegans (Link) (lichen) extract counteracts DNA damage and oxidative stress of mitomycin $\mathrm{C}$ in human lymphocytes. Cytotechnology. 64(6): 679-686 (2012).

32. S. ORTEGA-GUTIERREZ, M. LOPEZ-VICENTE, F. LOSTALE, L. FUENTES-BROTO, E. MARTINEZBALLARIN, J. GARCIA. Protective effect of melatonin against mitomycin $\mathrm{C}$-induced genotoxic damage in peripheral blood of rats. J. Biomed. Biotechnol. 2009: 791432 (2009).

33. E. KOTAN, L. ALPSOY, M. ANAR, A. ASLAN, G. AGAR. Protective role of methanol extract of Cetraria islandica (L.) against oxidative stress and genotoxic effects of $\mathrm{AFB}_{1}$ in human lymphocytes in vitro. Toxico. Ind. Health. 27(7): 599-605 (2011).

34. S. CEKER, F. ORHAN, H.E. KIZIL, L. ALPSOY, M. GULLUCE, A. ASLAN, G. AGAR. Genotoxic and antigenotoxic potentials of two Usnea species. Toxicol. Ind. Health. 31(11): 990-999 (2015).

35. R. SANTOS-MELLO, D. KWAN, A. NORMAN. Chromosome aberrations and T-cell survival in human lymphocytes. Radiat. Res. 60(3): 482-488 (1974).

36. C.J. NATH, T. ONG. Micronuclei assay in cytokinesisblocked binucleated and conventional mononucleated methods in human peripheral lymphocytes. Teratog. Carcinog. Mutagen. 10(3): 273-279 (1990).

37. H. NORPPA, G.C. FALCK. What do human micronuclei contain? Mutagenesis. 18(3): 221-233 (2003).

38. S. PETROVIĆ, A. LESKOVAC, G. JOKSIĆ. Positive correlation between micronuclei and necrosis of lymphocytes in medical personnel occupationally exposed to ionizing radiation. Arch. Oncol. 13(2): 65-68 (2005).

39. C.F. DE MOURA, J. NOGUTI, G.P. DE JESUS, F.A. RIBEIRO, F.A. GARCIA, A.P. GOLLUCKE, O.J.R. AGUIAR, D.A. RIBEIRO. Polyphenols as a chemopreventive agent in oral carcinogenesis: putative mechanisms of action using in vitro and in vivo test systems. Eur. J. Cancer. Prev. 22(5): 467-472 (2013).

40. L.R. FERGUSON. Role of plant polyphenols in genomic stability. Mutat. Res. 475(1-2): 89-111 (2001). 